\title{
高精度放射線がん治療技術と医学物理士の役割 理工系研究者の新たなキャリアパス
}

\author{
東京女子医科大学大学院医学研究科医学物理学分野 西尾 禎治
}

がんの三大療法の一つに放射線治療がある。放射線がん治療では，腫瘍に対して高線量を 集中させる様々な技術の研究開発が行われており, 強度変調放射線治療 (IMRT)や陽子線治 療といった高精度の放射線がん治療が可能となってきている。この高精度放射線がん治療技 術では, 理学および工学の知識を基盤とする医学物理学の研究開発が必要不可欠である。高 精度放射線がん治療の更なる発展においては, 理工系研究者の医学物理学分野へのキャリア パスによる研究開発の発展が非常に重要である。

\section{KEYWORDS: Medical Physics, Medical Physicist, High Precision Radiotherapy, Career path}

\section{I．放射線がん治療技術}

世界保健機関 (WHO : World Health Organization)の World Cancer Report によれば, 2020 年の世界での新規 がん患者数は 1,500 万人に達すると報告されている。 2018 年の日本のがん統計予測によれば，がん罹患数は 100 万例を超え, 死亡数は約 38 万人になるといわれてい

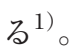

がんの三大療法は外科的手術, 放射線治療, 化学療法 である。がん治療で重要なことは, 単に治療するだけで なく, がんが治った後に, 元どおりの生活にもどれる「生 活の質 (QOL : Quality Of Life)」を維持することである。 このため, 人体の機能温存性の高いがん治療の一つであ る放射線治療が重要となる。なお, 放射線の医学利用に ついては, 1895 年にX 線が発見された翌年より研究が 始まっており，古く長い歴史がある。

がん治療で利用される主な放射線は, 光子線 $(\mathrm{X}$ 線, ガ ンマ線), 電子線, 重粒子線(陽子線, 炭素線, 中性子線な ど)である(図 1 参照)。重い粒子である重粒子線はがん細 胞に対して高い殺傷能力を持つ。また, 放射線がん治療 の標準的投与線量は, 1 回の照射で $2 \mathrm{~Gy}(1 \mathrm{~Gy}=1 \mathrm{~J} / \mathrm{kg})$ ほ ど, 総線量で 60〜 70 Gy ほどである。X 線および電子線 治療装置には, Varian 社の TrueBeam, Accuray 社の CyberKnife, 三菱重工の Vero などがある。重粒子線治療 装置には, IBA 社の陽子線, 東芝の炭素線, 住友重機の $\mathrm{BNCT}$ (ホウ素中性子捕捉療法)などがある。なお, BNCT は, がん細胞に集積するホウ素薬剤を患者へ投与し, 外部

Technology of high precision radiotherapy and the role of medical physicist; a new career path for science researchers : Teiji Nishio.

(2019 年 8 月 9 日 受理)

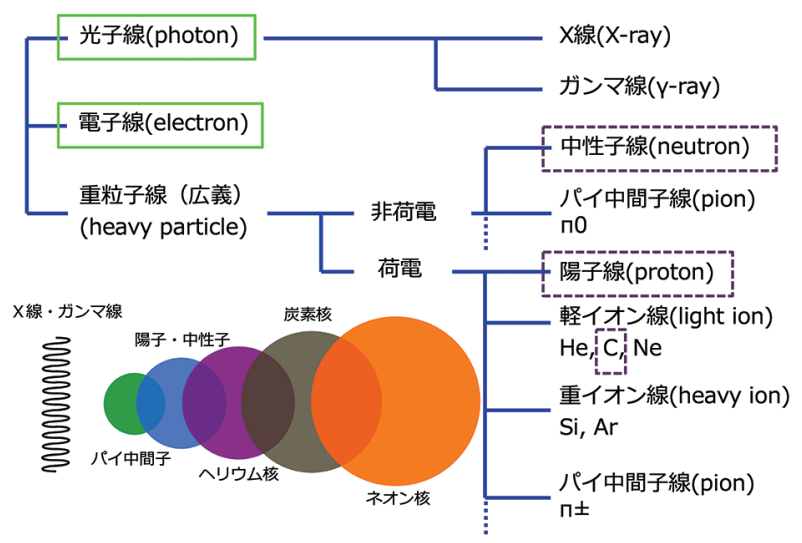

図 1 放射線の種類

実線枠掞よび点線枠で囲まれている放射線が，現在，放射線 がん治療で利用されている。

から熱外中性子を照射することで，がん細胞に集積した ホウ素核と中性子の原子核反応により放出されるアル ファ核とリチウム核によってがん細胞を殺傷する治療法 である。

近年の様々な技術進歩に伴い, 放射線がん治療技術は 日進月歩で進化を続けている。ここでは，その技術を活 用した高精度放射線がん治療の例として, 強度変調放射 線治療 (IMRT : Intensity Modulated Radiation Therapy) と陽子線治療について述べる。

\section{1. 強度変調放射線治療 (IMRT)}

一般的な放射線がん治療では，照射口から腫瘍形状に 沿った照射野で放射線をあてる。IMRTでは, コン ピュータ技術を駆使することで照射場所ごとに放射線 (X 線)の強度を変調させて, がん腫瘍だけに線量を集中 させる (図 2 参照)。腫瘍に対しては計画通りの高線量 を, 重要臓器に対しては可能な限りの低線量となるよう 

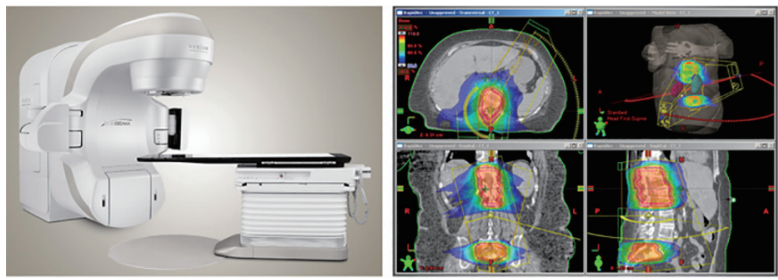

図 2 X 線・電子線治療装置および治療計画画面 強度変調放射線治療を可能とする放射線治療装置 (左図) 抒上 び治療計画装置の計画画面(右図)。

Varian ホームページより引用。

(https://www.varian.com/ja/oncology/products/treatment -delivery/truebeam-radiotherapy-system)

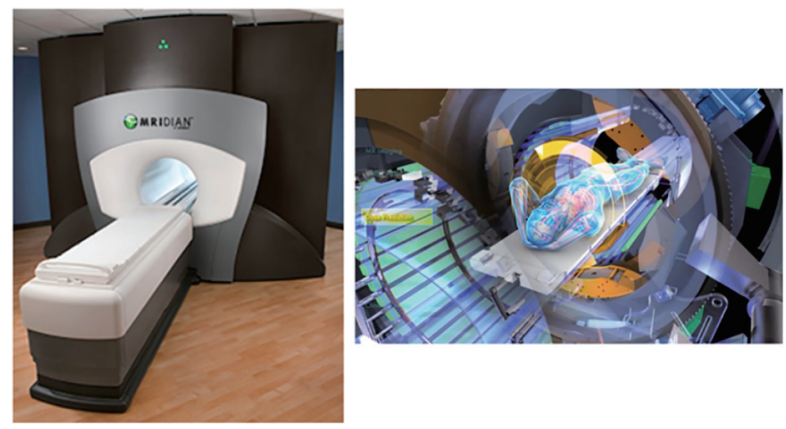

図 3 MRI 画像誘導 $X$ 線治療装置

MRI 画像誘導 $X$ 線治療装置 $($ 左図) および MRI 画像誘導 $\mathrm{X}$ 線治療の概念図 (右図)

View Ray ホームページより引用。

(http://www.viewray-japan.com)

に，照射線量強度の最適化計算(Inverse Planning)によ り照射線量強度マップ(Intensity Map)を作成して照射 する。放射線がん治療のメリットは，痛みがなく，15 分 程度の短時間ででき，患者に優しいことである。デメ リットとしては，腫瘍がどこにあるか簡単に見ることが できないことである。そのため, 放射線がん治療の際 に，患者体内中の何処に腫瘍があるのかを正確に見る目 の技術開発が重要である。そこで, 腫瘍位置を治療中も 正確に把握しながら放射線がん治療を行う装置も開発さ れつつある。図 3 は MRI 装置とX 線治療装置を融合さ せた MRI 画像誘導 X 線治療装置である。本装置を利用 することで，呼吸や心拍によって腫瘍位置が変動してし まう場合に扔いても, リアルタイムで腫瘍位置を把握 し，的確に腫瘍へX 線を照射することが可能である。

\section{2. 陽子線治療}

陽子線は体内中で停止する特性を持ち，停止する寸前 に大きな線量をその場に付与する。それにより媣部方向 の線量分布に形成される(拡大) ブラッグピークを活用す ることで，腫瘍に対して高線量を集中させたがん治療が 可能となる(図 4 参照)。国内で X 線治療施設数は 1,000 施設近くあるのに対し，陽子線治療施設数は 20 施設に も满たない。陽子線治療装置の大きさは, テニスコート 2 面分ほどの大きさがあり，医療機器としては非常に大

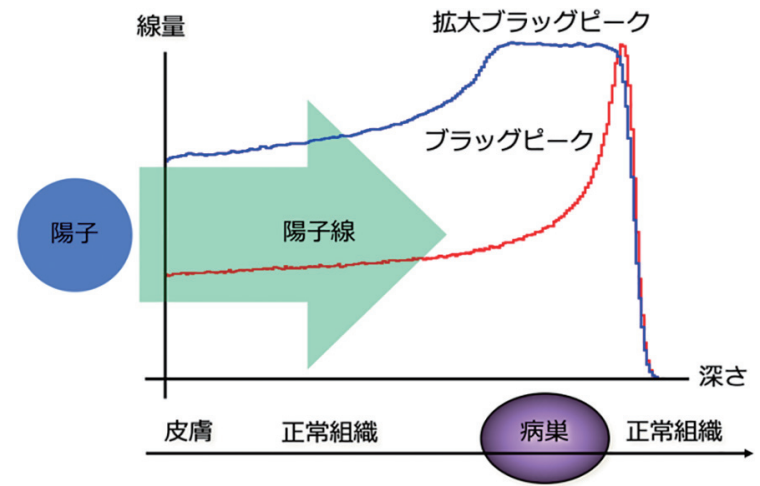

図 4 陽子線の深部線量分布

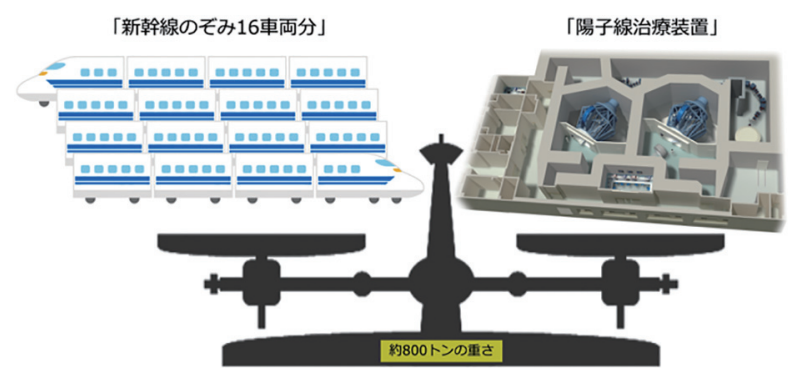

図 5 陽子線治療装置および重量の概念図 陽子線治療装置の図は住友重機械工業ホームページより引用。 (http://www.shi.co.jp/products/industry/proton/)

きく,コストも高額となるため導入が容易でない問題を 抱えている。陽子線加速器は, 陽子を $250 \mathrm{MeV}$ 程に加 速して, 腫瘍へミリ精度で照射する。陽子線回転ガント リー装置は, 直径 $10 \mathrm{~m}$ の回転構造物であり, ミリ精度 で 360 度回転し, 最適な方向から患者一陽子線を照射す る。陽子線治療装置の総重量は, 陽子線加速器と陽子線 回転ガントリー装置を持つ治療 2 室のレイアウトで, 新 幹線のぞみの車両 16 台分に相当する重さとなる (図 5 参 照)。陽子線の照射領域を形成するために精密機器が多 数配置されている。これらの精密機器が最適に設定され ることで, 側方均一線量分布形成, 深部均一線量分布形 成, 腫瘍形状線量分布形成などが行われ，患者の腫瘍の 形状や位置に合わせて最適な陽子線照射が可能となる。 また, 陽子が加速器から患者に照射されるまでの距離は 約 $30 \mathrm{~m}$ で, その飛行時間は僅か $150 \mathrm{~ns}=0.00000015$ 秒で あるが，その時間内に様々な方向から腫瘍へミリ精度で 陽子線を照射するための高度な技術が必要である。な お, 線量集中性の高い陽子線治療においては, 患者体内 中の腫瘍位置を正確に見る腫演位置決め装置, 患者体内 中の陽子線線量分布を精密に計算する線量シミュレー ション装置が活用される。陽子線治療の照射法として は, 通常のパッシブ照射法や肺や肝臟などの呼吸性移動 に伴って動く腫瘍へ対応した呼吸同期照射法, 更に久 キャニング照射法やそれを駆使した強度変調陽子線治療 (IMPT : Intensity Modulated Proton Therapy)がある (図 6 参照)。陽子線治療は照射技術の進歩と, それと同 時に装置の小型化への開発も進みつつある(図 7 参照)。 

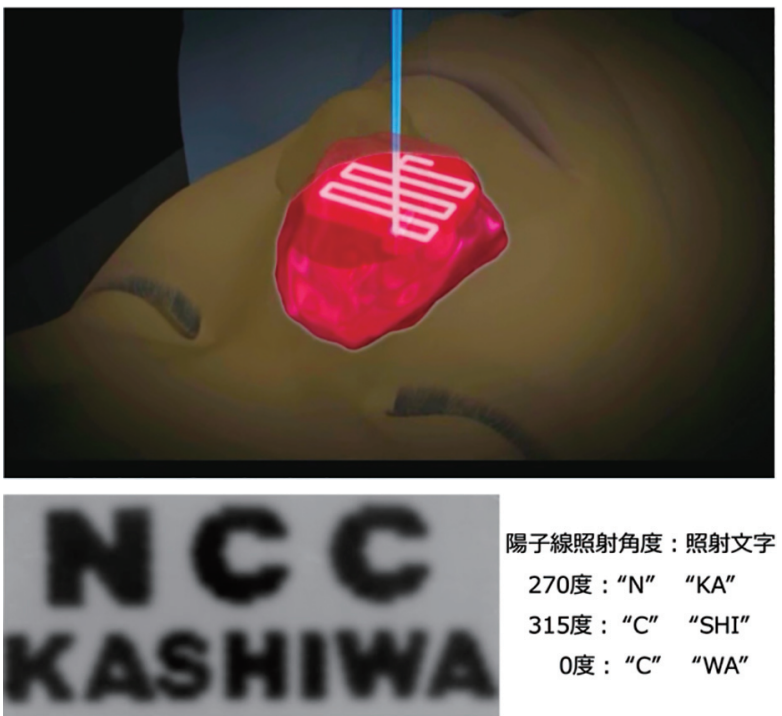

図 6 陽子線スキャニング照射法

陽子線スキャニング照射法の概念図 (上図)および“NCC KASHIWA”の文字を陽子線スキャニング照射法で線量フィ ルムに照射した実測例 (下図)。陽子線スキャニング照射法の 概念図は住友重機械工業ホームページより引用。 (http://www.shi.co.jp/products/industry/proton/)

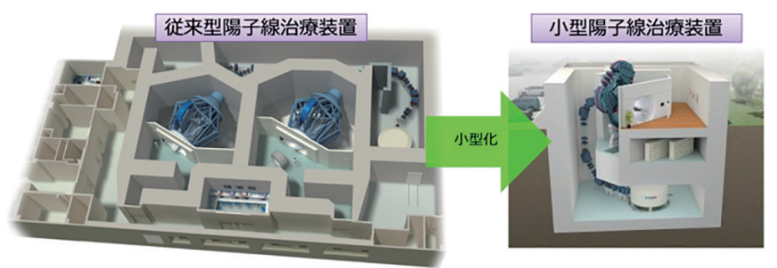

図 7 陽子線治療装置の小型化

陽子線治療装置の図は住友重機械工業ホームページより引用。 (http://www.shi.co.jp/products/industry/proton/)

\section{II. 医学物理学分野と医学物理士 ${ }^{3)}$}

高精度放射線がん治療は, 放射線物理学, 放射線計測 学, 電磁気学, 加速器物理工学, 統計物理学, 原子核物 理学などの幅広い物理学および工学の結集である。ま た, 照射システム, 画像システム, シミュレーションシ ステムなどの先端研究開発技術の集合体である。それら の知識および成果を医学へ展開する学術分野が医学物理 学分野である。

先に述べたように, IMRT や粒子線治療などの高精度 放射線がん治療では, 腫瘍への線量集中性が高い反面, 精度の高い治療計画や照射を行わなければ, 腫瘍への線 量投与が部分的に不足することでがんの治瘉率低下，ま た, 腫瘍周辺の重要臓器に高い線量が入ると重篤な障害 が起こる。そのため, 高精度放射線照射では, 正確にシ ミュレートして，正確に狙い，正確に照射することが重 要であり, それらの研究開発の実施が求められる。放射 線がん治療の高精度化には, 基礎物理学を基盤とする幅 広く融合された学術分野の知識と成果を活用した照射技 術, シミュレーション技術, 画像技術および検証技術に

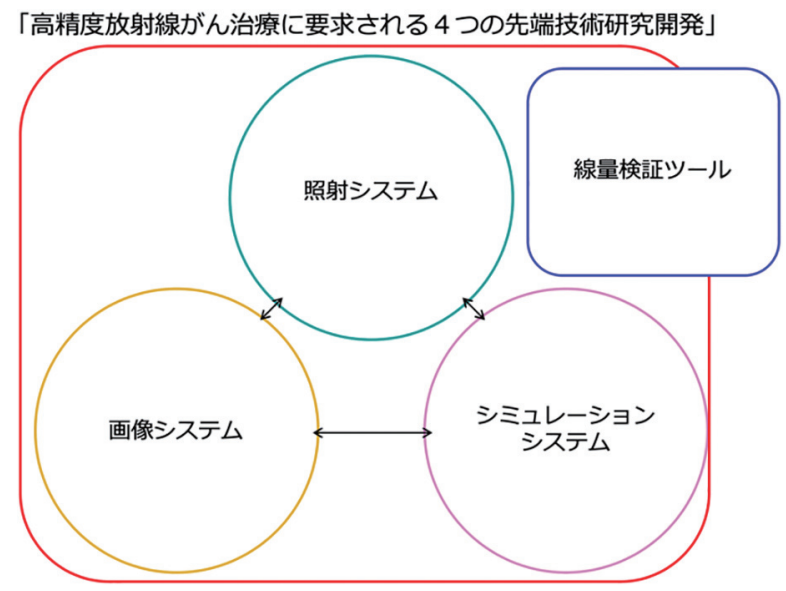

図 8 高精度放射線がん治療に要求される 4 つの先端技術研究 開発の概念図
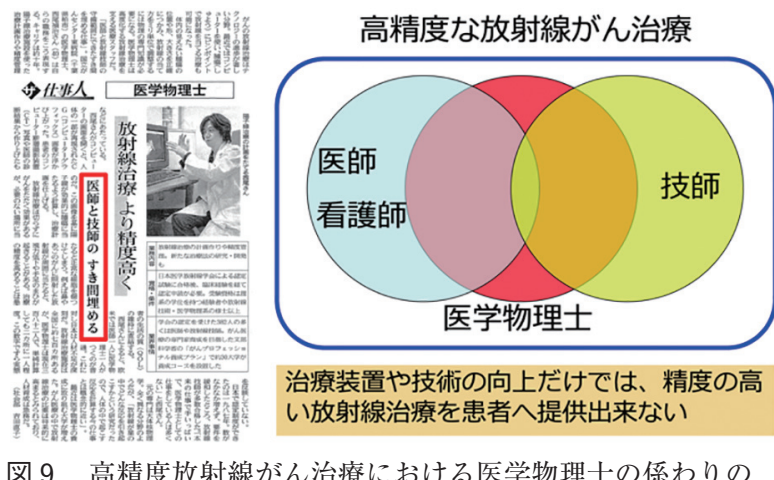

図 9 高精度放射線がん治療における医学物理士の係わりの 概念図

関する高度な研究開発が必要不可欠である (図 8 参照)。 そのため, 大学や研究所においては革新的な医学物理学 研究および開発, 研究者の育成を主体的に実施する人材 が重要となる。また，医療現場においては，放射線がん 治療が高度化する一方, その治療装置や技術の品質保証 および管理の項目は，より一層の複雑化を招いている。 その結果, 治療装置や技術の品質保証および管理の業務 は非常に幅広い領域で多岐にわたり，現場の医療従事者 の負担増になり，それらの業務の中心的役割を担う人材 が求められる。そのような医学物理学の研究開発から医 療現場での治療の品質を担保する職種が医学物理士であ る。医療現場における医学物理士は, 患者ごとの治療計 画や投与線量精度の管理, 治療装置の精度や性能の維持 管理および向上に貢献することで，放射線治療医師と診 療放射線技師の間を繋ぐ役割を担っている(図 9 参照)。 また, 医学物理学分野の発展・進歩において, 医学物理 学研究開発や人材育成で貢献することも医学物理士の重 要な業務である。

医学物理士という職は欧米などの先進国では非常に人 気のある職である。そして，その医学物理士の多くは放 射線物理系研究をバックグラウンドとする研究者であ る。その一方, 日本国内では, まだそれ程, 医学物理士 の認知度は高くない状況にある。日本国内の医学物理士 
は機構が認定する資格であり，現在，約 1,200 名の資格 保有者がいる2)。欧米と比較してその人数はまだ少な く，また，日本特有の様々な事情のため，医学物理士の 資格を有していても医学物理士の職に就いていない人が 数多い。日本国内の多くの病院で医学物理士を採用した いといった需要があるにも関わらず，現状として，実際 に医学物理士の職に就いている人は資格保有者数の $1 / 4$ 以下でしかない4)。日本国内に扔けるがんの放射線治療 関連施設で働く医学物理士の数の不足は, 高品質の放射 線がん治療を患者へ提供する上で深刻な問題である。こ の問題解決のためには，医療のニーズを知ることでシー ズを生み出すことが出来る, 研究実施能力を持った人材 が必要である。

\section{III. 理工系研究者の医学物理士へのキャリアパス ${ }^{3)}$}

医学物理士は放射線がん治療の高精度化に関する研究 開発業務や高品質化のための医療業務を通して, それら の成果を最終的に患者や社会へ届けることができる，非 常に需要の高い医療専門職である。放射線医療におい て，基礎を十分に学んできた理工系出身の若手研究者は 医学物理士の卵として大いに期待されており，医学分野 は放射線物理学を学んだ研究者の新たなキャリアパスに なると思われる。特に放射線医療に打ける医学物理学分 野の研究開発や放射線管理は原子力分野と多くの共通点 がある。放射線物理学に関する研究開発は勿論のこと, 放射線がどんな基礎特性を持つかを計測，シミュレー ション等を駆使することで把握し，また，その上で放射 線をどのような手法や技術で管理するかなど，日々の放 射線がん治療現場で医学物理士が取り組んでいる業務な どは原子力事業に係わる専門家と同じような業務内容で あると推測する。そこで，その一歩として，放射線に関 する専門家である原子力分野との連携を行うことで，放 射線物理学の専門知識を必要とする医学物理士という医 療分野で活躍できる専門職があることを若手研究者など に広く知って貫い, 人材育成や研究開発において協力連 携体制を構築できることを切に願っている。

理工系研究者が医学物理学分野へキャリアパスをした 場合，その魅力は様々である。その魅力の例(個人的意 見)は以下の通りである。

・“がん患者の治療のため”といった明確な目的を持つこ とが出来る。

・“医療人としての自覚と責任感”を持つことが出来る。 ・様々な職種の方との協力体制の下で, 研究面だけでな く人格形成面でも“幅広い視野”を養うことが出来る。 ・短期間で結果が出せるものから結果が出るまで長期間 必要となるものまで“研究テーマが数多く存在”する。

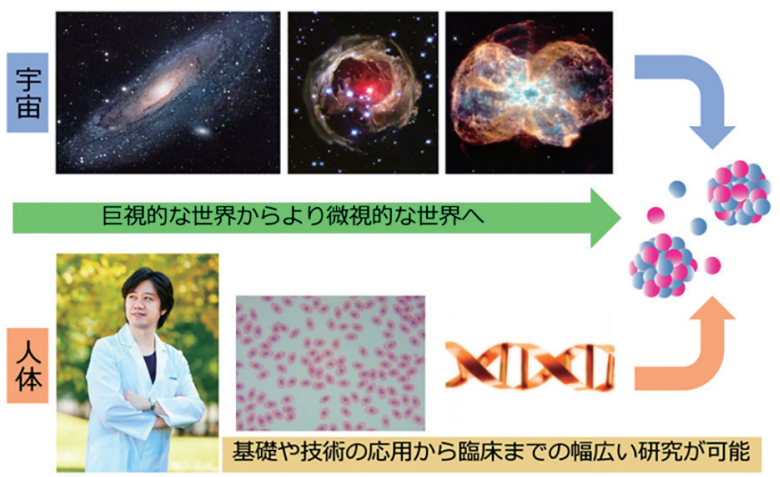

図 10 理工系研究者と医学物理学研究の係わり概念図

・国内ではまだ確立されていない分野であるので，努力 次第では “医学物理分野のパイオニア”になることが 出来る。

また，医学物理学の研究は宇宙物理学などの基礎的な 研究に似ている側面を持ち, 基碛研究から技術応用, 更 には臨床に至るまでの幅広い研究抢よび開発が可能であ ることも魅力の一つである(図 10 参照)。

最後に, インターネット上で医学物理士を検索すると 様々な情報が流れている。その情報の中には医学物理士 は理工系出身者の学生や研究者のキャリアパスにならな いような記述内容のものまであるが, 実際のところ, 決 してそうではない。もし，医学物理学の分野に興味があ る方は, 既に医学物理学分野にいる我々のような理工系 研究出身者とコンタクトを取って正しい情報を収集して 欲しい。理工系研究者は未来を担う医学物理士として期 待されている。今後, 是非とも医学物理学分野を将来の 進路候補の一つとして考えて頂きたい。

\section{一 参 考文献 -}

1）国立がん研究センターがん情報サービスホームページ： https://ganjoho.jp/reg_stat/statistics/stat/short_pred.html 2) 一般財団法人医学物理士認定機構ホームページ： http://www.jbmp.org

3) 西尾禎治, 解説 “がんの放射線治療における医学物理士の現 状と課題, ”原子力システム研究懇話会発行_原子力システム ニュース Vol.30,No.1,33-35.

4) N. Tohyama, H. Okamoto, T. Nishio, “Questionnaire Survey of Japanese Medical Physicists for Working Conditions in 2014, Jpn. J. Med. Phys. Vol.36(1), 2-17(2016).

\section{著者紹介}

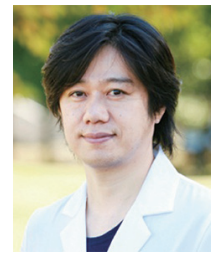
西尾禎治（にしお・ていじ） 東京女子医科大学大学院医学研究科 医学物理学分野 (専門分野/関心分野) 医学物理学分野 